\title{
The Application of Situational Education Method in Art Appreciation Course in Primary School
}

\author{
Ning Zhu \\ Zhejiang A\&F University, Hangzhou 310000, China
}

Abstract: With the increasingly improvement of teaching quality, primary education has aroused widespread attention in the education sector. Situational teaching method has become a popular and useful teaching method. In primary school it enables students to appreciate the beauty, feel the beauty, enjoy the charm of art, stimulate learning interest, cultivate basic aesthetic ability. In that case can we better achieve the teaching purpose.

Keywords: Primary School Art Teaching; Situational Teaching; Learning Initiative

Motivate students' emotion, which is the mutual collision of emotion and cognition., is the core of situational teaching. Through the combination of children's cognition and emotion, we can enter the teaching situation harmoniously. Students can be immersed in the classroom through music, physical objects, and other forms of ways. In the other word, we stimulate their enthusiasm of learning, so we achieve the goal. Especially for the students with low self-control, situational teaching method can effectively attract their attention and make the classroom no longer boring and boring, but become lively and interesting. The scene created in the classroom is not only the combination of object and form, but also the stimulation of children's emotion and the intuitive sublimation of their understanding of the "environment" of the object, and the combination of image thinking and abstract thinking ${ }^{[1]}$. Among them, there are subtle suggestive effects, which can make children pay attention to the focus and be full of spirit for classroom learning. It can effectively exercise students' creative thinking, improve their understanding and participation in the classroom, to better improve the teaching level of primary school art appreciation and cultivate students' comprehensive ability.

\section{Advantages of situational teaching method}

\subsection{Vividness}

Situational teaching method, which can fully create the classroom atmosphere and scene of art appreciation teaching in primary school, is vivid. During the teaching process, teachers use reasonable means to make full use of multimedia resources. Through the guidance of pictures, music and other situations, teachers can encourage students' interest in learning from the psychological point of view. Change the opinion "want me to learn" into "I want to learn", which is able to effectively cultivate students' art appreciation ability and creativity, and sincerely lead students to understand the emotion, expression and sustenance of art works. Using situational teaching method and multimedia resources, teachers can break away from the previous rigid and monotonous teaching mode ${ }^{[2]}$. Thus, it will make the classroom teaching form become rich and colorful, improve students' initiative and participation in classroom learning. To inspire students' initial desire to explore the art field, and make learning activities a happy thing for students to actively carry out. Through the teacher's analysis, students can learn the art knowledge of color, form, composition and other art knowledge in the picture more actively, What's more, they will listen carefully in the classroom, in the other word, we can say they enhance the ability of self-control. In the process of art appreciation teaching, vivid situational teaching plays an important role in attracting jade. It guides students to learn art knowledge in a comfortable classroom and turns

Copyright $\odot 2020$ Ning Zhu

doi: $10.18282 /$ le.v9i7.1481

This is an open-access article distributed under the terms of the Creative Commons Attribution Non-Commercial License

(http://creativecommons.org/licenses/by-nc/4.0/), which permits unrestricted non-commercial use, distribution, and reproduction in any medium, provided the original work is properly cited. 
learning into an active and happy thing ${ }^{[3]}$.

\subsection{Intuition}

The application of situational teaching method in primary school art appreciation class can help students understand the knowledge in class more intuitively and effectively. The intellectual development of primary school students is not comprehensive enough. Therefore, making children feel "situation is in front of their eyes" and "I am in the situation" can help them understand. Knowledge points become popular and easy to understand, and students' learning enthusiasm is also improved. In the classroom, combined with modern teaching equipment such as multimedia projection, VR technology interaction, and making full use of modern advanced equipment, the static image is transformed into visual intuitive expression language, so that students can more intuitively feel the unique charm of art, learn to appreciate, and deepen the impression and perception of famous works. Through the scene restoration, students can deepen the intuitive memory of art works, and use it in their own art creation. In the process of painting, they can think more about lines, colors, strokes, composition, and other angles, so as to arouse their attention to the beauty of the picture ${ }^{[4]}$.

\subsection{Interest}

Emotion and interest are two important factors in the process of art education in primary school. Teachers use situational teaching method to improve students' curiosity about art works according to their current psychological level, so that students can actively understand the creative background, ideology, and cultural connotation of works. After the students appreciate the famous paintings, the teacher guides the students to fully divergent thinking through discussion, so that the children's potential intuition can burst out the spark of thinking under the collision of external favorable factors, thus playing the role of ideological enlightenment. The curiosity of primary school students comes from the sense of atmosphere. They will pay high attention to the novel things and actively participate in it. Situational teaching method makes use of this nature of children to increase the participation in the classroom and promote the harmonious relationship between teachers and students, so as to improve the quality and efficiency of teaching ${ }^{[5]}$.

\section{The application of situational teaching method in primary school art appreciation}

\subsection{The teaching method of audio-visual combination is adopted}

The core of situational teaching method is to stimulate students' emotions, and its advantage is to give the boring works a sense of experience and substitution, making art appreciation class a pleasant and relaxed visual feast. Students' ability of understanding and self-control is low, so how to let them actively appreciate art has become the difficulty of this course teaching. With the advent of the information age, all walks of life are looking for opportunities to combine with the information age, and so is the education sector ${ }^{[6]}$. Therefore, in the teaching of art appreciation course, we should make full use of multimedia resources to provide atmosphere. In the past art appreciation courses, teachers usually tell students knowledge points with the help of pictures and texts in books. This kind of mechanical education mode makes it impossible to complete good interaction in the classroom. Students often passively accept information and can't really feel the beauty of art. Therefore, we should change the traditional boring teaching method and use the teaching concept of audio-visual combination to let primary schools Students go deep into their surroundings and feel the charm of art. We can add games to the classroom to attract students' attention, so that children can imperceptibly accept knowledge in the process of games, and improve students' adaptability to classroom learning. Play music in the picture explanation, create an atmosphere, let the children live in the scene, better feel the emotion of the artist's creation, can also be better applied to the creation of students, improve the efficiency of classroom learning ${ }^{[7]}$.

\subsection{Reasonable classroom layout}

Classroom layout should be combined with teaching theme, so that pupils can have corresponding emotional experience in specific color and atmosphere. For example, when appreciating Van Gogh's sunflower, the teacher can prepare some sunflowers and distribute them to the children, so that the children can describe them, increase their understanding of the shape of sunflowers, and then explain the famous paintings ${ }^{[8-9]}$. In order to make students have a better understanding of the painter's emotion, we can combine the short film of the artist's life with the age of the 
work creation, so that students can have a deeper understanding of the works and enlighten them with the background of creation. Creating a thematic situational teaching classroom can increase the interest and participation of the classroom $^{[10]}$.

\section{Epilogue}

The former teaching methods have been difficult to adapt to the development of the times, so teachers in order to better teaching purposes, their teaching methods must keep pace with the times. Teachers should make full use of situational teaching method, give full play to its advantages, improve students' enthusiasm and classroom participation, and turn passive to active. Through the relaxed and pleasant classroom atmosphere, let children get ideological enlightenment, give full play to children's creativity, achieve the basic requirements of art appreciation course for students, and promote the overall development of students in all aspects.

\section{References}

1. Hu Bin. On “Teaching” and "Learning” of Art Appreciation Class in Primary Schools [D]. Master's Thesis of Inner Mongolia Normal University, 2017.

2. Wang Baijuan. Research on the Application of situational Teaching method in art Appreciation Course teaching in Junior High School [J].Learn weekly, 2018 (4) : 165-166.

3. Wang Xiaoxia. The Importance of Situational Teaching [J]. Primary School Students (Teaching Practice),2012(02):76.

4. CAI Yanmei. A Brief Discussion on situational Teaching Method [J]. Essay On The Road to Success (Part 2),2012(07):41.

5. You Qi. Reform and Innovation of fine arts Education in Primary Schools under the New Curriculum Concept [J]. Research on Fine Arts Education,2020(01):148-149.

6. Wang Zhongling. Research on Situational Teaching of Art Education in Primary Schools [J]. Intelligence, 2019(35):112.

7. Yang Jie. Research on Problems and Countermeasures of Art Education in Primary Schools [J]. Research on Art Education,2015(16):114.

8. LAN Ling. Application of Situational Teaching Method in Primary School Chinese [J]. Knowledge Library, 2018, 000(017):P.84-84.

9. Aimei. On the Application of Situational Teaching Method in Primary School Chinese Teaching [J].Extra-curricular Languages, 2019, 000(021):P.56-57.

10. Dai Wei. Application Strategy Analysis of situational teaching Method based on primary school art Core Literacy [J]. Exam Weekly,2020(74):139-140. 